\title{
Monitoring for Methane Gas in Carbon and Emery Counties, Utah, 1995-2003
}

\section{Prepared in cooperation with the Utah Department of Natural Resources, Division of Oil, Gas, and Mining}

Substantial production of methane gas has come from coal beds in central Utah (fig. 1) since the early 1990s. Methane is generated as a byproduct during formation of coal and released when ground water is pumped from geologic formations that contain coal beds.

Methane gas in Carbon and

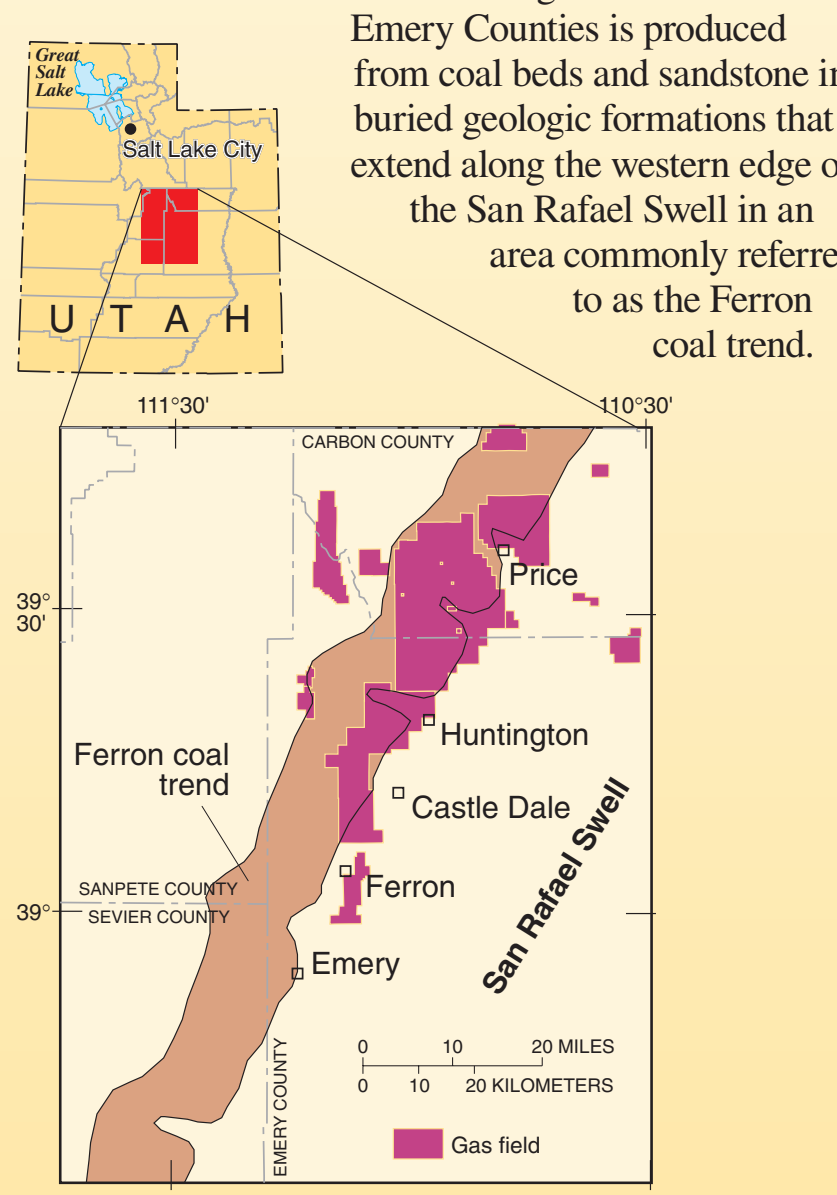

Figure 1. Generalized area of coal-bed methane development, Carbon and Emery Counties, Utah, 1985-2003.

The coal trend extends underneath the towns of Price, Huntington, Castle Dale, Ferron, and Emery. Depth to the geologic formations from land surface ranges from 1,000 to 4,500 feet (Tabet and others, 1995; Stevens, 1993). Methane gas is recovered through boreholes that are drilled into the formations with a variety of different drilling, completion, and extraction technologies (Stevens, 1993). Gas is released when the hydrostatic pressure cre- ated by overlying water is reduced by pumping water out of the formations. Almost all of this water is currently (2006) disposed of by injecting it back into even deeper geologic formations.

Methane gas is a fuel commonly burned in furnaces and water heaters. It is released when water is pumped from coal beds.

When water pressure is reduced, methane gas flows from the coal into the well bore. Methane is lighter than air and rises through the well to land surface where it is gathered into a pipeline system. This diagram shows one possible type of well construction. 


\section{Monitoring Program}

Release of methane gas from coal beds creates the potential for it to move into near-surface environments through natural and humanmade pathways. Natural pathways include fractures through the rock layers and voids between the grains of rock. Human-made pathways can be created when various types of wells are drilled. To help ensure the safety of communities and to deter-
Methane gas concentration is reported in parts per million by volume (ppmv). As an example, an air sample with a methane concentration of 1,000 ppmv would contain 1,000 molecules of methane for every $1,000,000$ molecules of air.

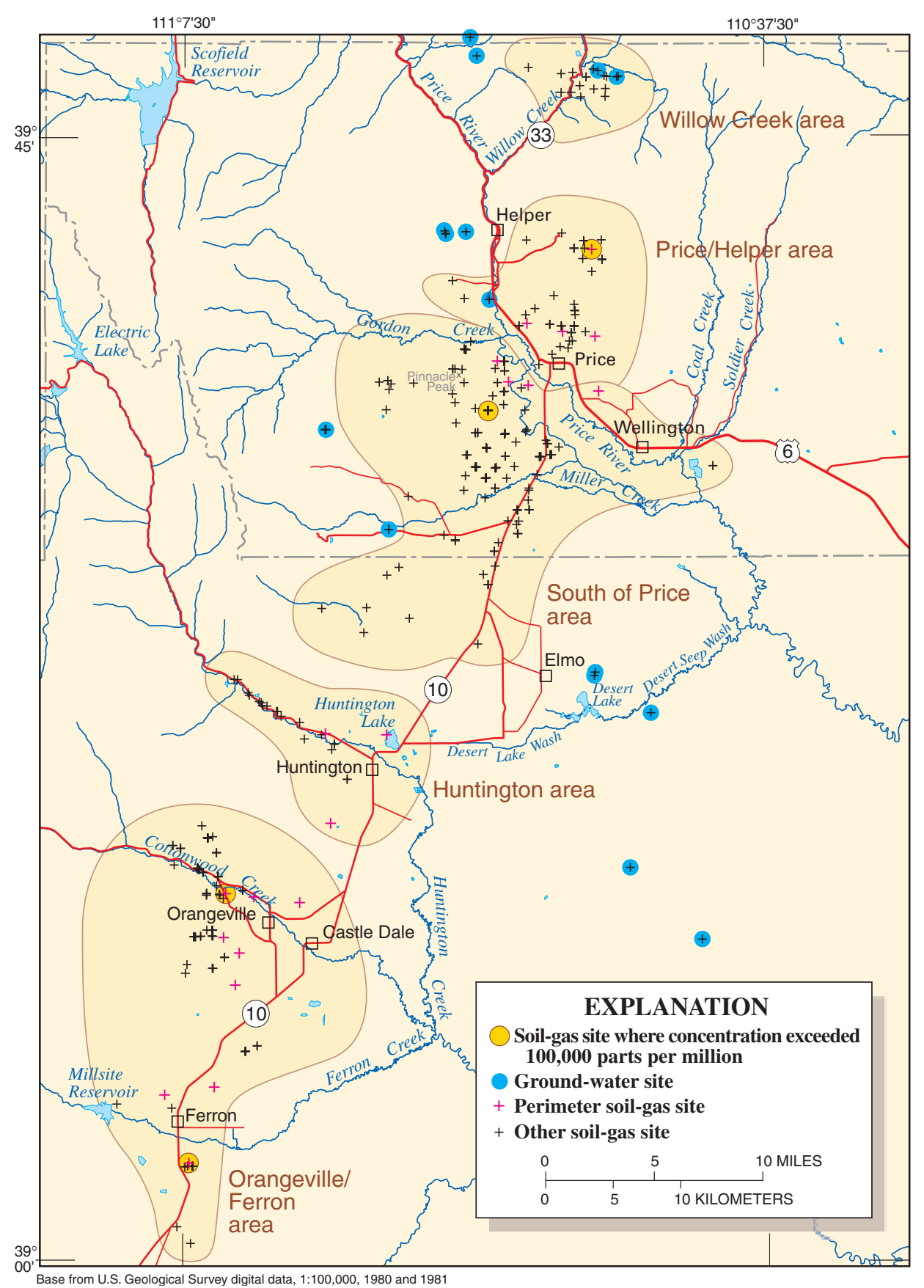

Figure 2. Location of sites where samples were collected and analyzed for methane concentration in Carbon and Emery Counties, Utah, 1995-2003. mine the potential impact from development of coal-bed resources, the U.S. Geological Survey and the Utah Department of Natural Resources, Division of Oil, Gas, and Mining, cooperated in a program to monitor methane gas concentration in soils and ground water in areas of coalbed methane production. Monitoring took place from 1995 through 2003. Monitoring results and techniques for the period from 1995 through April 1997 are discussed in an initial fact sheet by Naftz and others (1998). This fact sheet summarizes information for the entire monitoring period. Data and the interpretations generated by the monitoring program are published in Stolp and others (2006).

Monitoring focused on established production-well sites and methanegas production fields near residential areas. A priority was to identify and quantify trends and establish baseline methane concentrations in the soil and (or) ground water for future comparison. A core of twenty perimeter sites was established around Price, Huntington, Orangeville, and Ferron (fig. 2). These sites were monitored annually to determine whether methane concentrations were increasing near populated areas. Additional sites were established to monitor expanding areas of production and newly drilled production wells. A total of 420 soil-gas and ground-water samples were collected at 189 sites and analyzed during 1995-2003 (fig. 2).

Inside buildings, methane concentrations above 1 percent $(10,000$ ppmv) are considered dangerous. Outside air can catch on fire if methane concentration exceeds 5 percent (50,000 ppmv). 


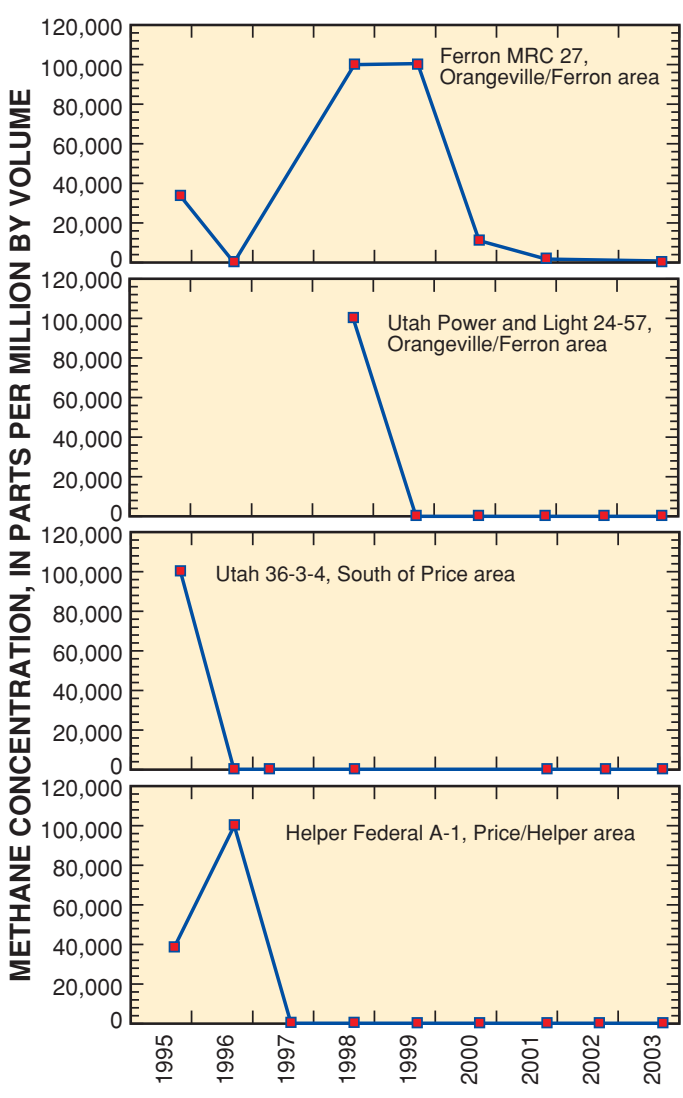

Figure 3. Long-term trend at monitoring sites at which the highest concentrations of soil-gas methane were measured, Carbon and Emery Counties, Utah, 1995-2003.

\section{Presence of methane gas}

On the basis of spatial and temporal methane concentration data collected during the 1995-2003 monitoring period, there does not appear to be an obvious, widespread, or consistent migration of methane gas into populated areas. The average measured methane concentration for the monitoring period was 2,740 parts per million by volume (ppmv); the median concentration was less than 10 ppmv. Two hundred and ten samples (50 percent of the sample set) had concentrations that were less than 10 ppmv. Twenty samples (5 percent of the sample set) had concentrations above 10,000 ppmv. Air can catch on fire if methane concentration exceeds 50,000 ppmv. Inside buildings, a concentration above $10,000 \mathrm{ppmv}$ is potentially dangerous. At a concentration of less than 5,000 ppmv, methane poses no immediate threat (Eltschlager and others, 2001, p. 34-37).
Summary statistics of methane concentration for five areas of coal-bed production (fig. 2 ) are listed in table 1 . None of the production areas had average concentrations that are considered to be dangerous (greater than 5,000 ppmv). The median concentration for all areas is less than the average value, indicating that most values in the sample set are less than the average value. Twenty samples from 11 sites had methane concentrations that exceeded 10,000 ppmv. Those sites are scattered across the entire area and do not indicate specific locations of high concentrations.

At 75 sites, soil-gas samples were collected multiple times during the monitoring period. These data show a general trend of decreasing methane concentration over time. At sites where concentrations of $10,000 \mathrm{ppmv}$ or greater were measured at some time during the monitoring period, the most recent repeat measurements averaged 23 ppmv methane. Methane concentrations over time at sites with the highest concentrations (greater than 100,000 ppmv) are shown in figure 3 . These high concentrations might be associated with disturbances to the geohydrologic conditions that occur during drilling of coal-bed gas wells or problems
On the basis of samples collected, there does not appear to be an obvious or consistent migration of methane into populated areas.

with well maintenance. It is common to see high methane concentrations shortly after drilling. If wells are properly constructed and maintained, concentrations that result from drilling generally decrease and remain low over time.

Monitoring of methane concentrations in ground water was limited. An initial inventory of coal-bed methane production areas in 1995 resulted in sample collection from 14 sites that included springs, drains, and ponds. The average methane concentration was 20 ppmv. Multiple samples were collected at a single spring site during 2000-2002. Methane concentration at that site decreased from 26,200 ppmv in 2000 to 160 ppmv in 2002.
Table 1. Summary statistics of methane concentration for five areas of coal-bed production, Carbon and Emery Counties, Utah, 1995-2003.

\begin{tabular}{|c|c|c|c|c|c|}
\hline Area & $\begin{array}{c}\text { Average } \\
\text { conventration } \\
\text { (ppmv) }\end{array}$ & $\begin{array}{c}\text { Median } \\
\text { conventration } \\
(\text { ppmv })\end{array}$ & $\begin{array}{c}\text { Minimum } \\
\text { conventration } \\
(\text { ppmv })\end{array}$ & $\begin{array}{c}\text { Maximum } \\
\text { conventration } \\
(\text { ppmv) }\end{array}$ & $\begin{array}{c}\text { Number of } \\
\text { samples }\end{array}$ \\
\hline Willow Creek & 800 & $<10$ & $<10$ & 6,390 & 15 \\
\hline Price/Helper & 2,260 & 10 & $<1$ & $>100,000$ & 75 \\
\hline South of Price & 1,750 & $<10$ & $<1$ & $>100,000$ & 152 \\
\hline Huntington & 15 & 4 & $<1$ & 160 & 24 \\
\hline Orangeville/Ferron & 4,920 & $<10$ & $<1$ & $>100,000$ & 137 \\
\hline
\end{tabular}




\section{Well-Field History and Development}

Pilot development of coal-bed methane resources began near Price, Utah, in 1985. By 1991, methane production had spread south to Orangeville and Ferron, and as of November 2003, there were 772 coal-bed methane wells (fig. 4). Regulatory agencies continue (2006) to receive applications to drill additional coal-bed methane wells in the area, however, at a much slower pace than in the past. The eventual number of wells will be determined primarily by the physical and economic limitations of the gas resource.

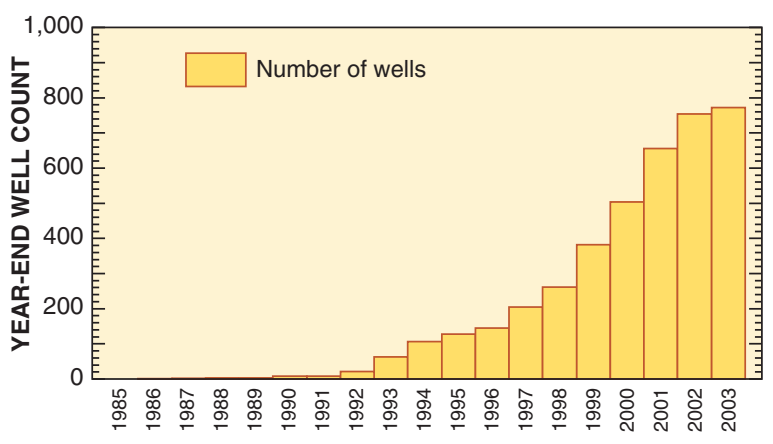

Figure 4. Number of coal-bed methane gas-production wells, Carbon and Emery Counties, Utah, 1985-2003.

\section{Collection and Analysis of Methane Samples}

Soil-gas samples are collected by inserting a perforated steel pipe 2 to 4 feet into the ground. Air is pumped from the pipe and tested for methane by using a gas chromatograph equipped with a flame ionization detector. A detailed description of the sampling process is provided in Stolp and others (2006).

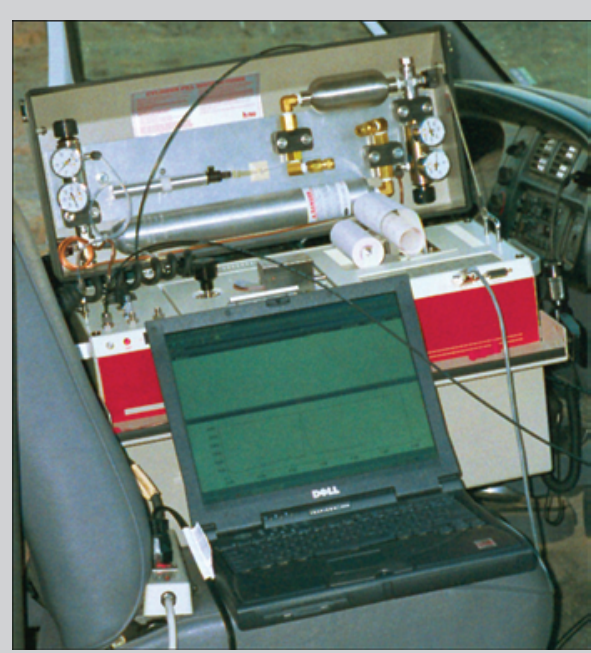

Portable gas chromatograph with a flame ionization detector.

\begin{abstract}
Total methane produced from the Ferron coal trend from 1992 to 2003 is approximately the amount needed to heat 500,000 Utah homes for 8 years.
\end{abstract}

Any use of trade, firm, or product names is for descriptive purposes only and does not imply endorsement by the U.S. Government.

\section{References Cited}

Eltschlager, K.K., Hawkins, J.W., Ehler, W.C., and Baldassare, Fred, 2001, Technical measures for the investigation and mitigation of fugitive methane hazards in areas of coal mining: Pittsburgh, Pa., U.S. Department of the Interior, Office of Surface Mining Reclamation and Enforcement, Appalachian Regional Coordinating Center, 124 p. accessed May 22, 2006, at http://www.osmre.gov/rep.htm

Naftz, D.L., Hadley, H.K., and Hunt, G.L., 1998, Determination of methane concentrations in shallow ground water and soil gas near Price, Utah: U.S. Geological Survey Fact Sheet FS191-97, 4 p.
Stevens, S.H., 1993, Exploration and development, Uinta Basin, Utah: Quarterly Review of Methane from Coal Seams Technology, v. 11, no. 1, p. 38-42.

Stolp, B.J., Burr, A.L., and Johnson, K.K., 2006, Methane gas concentration in soils and ground water, Carbon and Emery Counties, Utah, 1995-2003: U.S. Geological Survey Scientific Investigations Report 2006-5227, 19 p.

Tabet, D.E., Hucka, B.P., Sommer, S.N., 1995, Maps of total Ferron coal, depth to top, and vitrinite reflectance for the Ferron Sandstone Member of the Mancos Shale, central Utah: Utah Geological Survey Open-File Report 329, 3 pls., scale 1:250,000.
Sources of Additional Information

Hydrologic and additional methane concentration data in Carbon and Emery Counties, Utah, may be obtained from:

U.S. Geological Survey Utah Water Science Center 2329 Orton Circle

Salt Lake City, Utah 84119-2047 (801) $908-5000$

Utah Department of Natural Resources Division of Oil, Gas, and Mining 1594 West North Temple, Suite 1210 Box 145801

Salt Lake City, Utah 84114-5801 (801) 538-5297

-By Andrew L. Burr, Bernard J. Stolp, and Kevin K. Johnson-U.S. Geological Survey; and Gilbert L. Hunt-Utah Department of Natural Resources, Division of Oil, Gas, and Mining 